\title{
JORNALISTAS EM VEÍCULOS E ASSESSORES: PAPEIS DIFERENTES; MESMO CÓDIGO DE ÉTICA
}

\author{
Journalist in newspapers and press oficcers: different roles; same ethics code \\ Periodistas em la prensa y asessores de prensa: papeles diferentes; mismo \\ código de ética
}

Mário Messagi Jr.

Professor de Comunicação na Universidade Federal do Paraná

mmessagi@gmail.com

\section{Resumo}

Assessores de imprensa são jornalistas? Esta questão divide profissionais e pesquisadores. Alberto Dines, por exemplo, defende o modelo português, que separa moralmente assessoria de jornalismo. Eugênio Bucci advoga que são duas profissões diferentes e, utilizando a comparação com o campo jurídico, aponta conflitos morais evidentes. Através de uma discussão normativa, comparando a deontologia do jornalismo com a do direito, este artigo pretende demonstrar o contrário. Não há esta separação estanque de profissões entre o juiz e o advogado, todos os agentes se vinculam ao mesmo norte moral. A área de assessoria de imprensa no Brasil se desenvolveu de maneira singular e mais comprometida com os direitos do cidadão. Dentro do sistema jornalístico, ela se vincula aos valores morais do jornalismo, ainda que não tenha, estritamente, as mesmas obrigações que os jornalistas de redação. Adotar qualquer concepção que vincule a assessoria de imprensa às práticas da comunicação instrumental é caminhar para trás.

Palavras-chave: Assessoria de imprensa. Direito. Profissões.

\begin{abstract}
Press officers are journalists? This question divides professionals and researchers. Alberto Dines, for example, defends the Portuguese model, which separates, for moral reasons, journalism and press office. Eugenio Bucci argues that they are two different professions and, using the comparison to the legal field, points clear moral conflicts. Through a normative discussion by comparing the ethics of journalism with the law, this article argues otherwise. There is no tight separation of professions between the judge and the lawyer, all agents are linked to the same moral guideline. The press office area in Brazil has developed a unique and more committed way with the rights of citizens. Within the journalistic system, it is linked to the moral values of journalism, although it does not strictly have the same obligations as editorial journalists. To adopt any conception that links the press office to the practices of instrumental communication is to move backwards.
\end{abstract}

Key words: Press office. Law. Professions. 


\begin{abstract}
Resumen
¿Asesores de prensa son periodistas? Esta pregunta divide a los profesionales e investigadores. Al ejemplo Alberto Dines defiende el modelo portugués, que aparta el periodismo y la oficina de prensa moralmente. Eugenio Bucci defiende que son dos profesiones diferentes y utilizando la comparación con el ámbito jurídico, puntos de ventaja conflictos morales. A través de una discusión normativa mediante la comparación de la ética del periodismo y del derecho, este artículo sostiene lo contrario. No hay esta rígida separación de profesiones entre el juez y el abogado, todos los agentes están conectados a la misma directiva moral. El área de la oficina de prensa en Brasil ha desarrollado una forma única y más comprometida con los derechos de los ciudadanos. Dentro del sistema periodístico, se vincula a los valores morales del periodismo, aunque no tenga, estrictamente, las mismas obligaciones que los periodistas de redacción. Adoptar cualquier concepción que vincule la asesoría de prensa a las prácticas de la comunicación instrumental es caminar hacia atrás.
\end{abstract}

Palabras clave: Oficina de prensa. Derecho. Profesiones.

\title{
1 INTRODUÇÃO
}

Assessores de imprensa são jornalistas ou não? Esta questão divide opiniões entre os profissionais da área há décadas e materializa os rastros da polêmica inclusive na deontologia da profissão. Desde 2007, o Código de Ética dos Jornalistas Brasileiros prevê que assessores não são obrigados ao princípio do amplo contraditório, um dos dois pilares fundamentais da atividade jornalística. Diz o texto:

Art. 12. O jornalista deve: I - ressalvadas as especificidades da assessoria de imprensa (grifo do autor), ouvir sempre, antes da divulgação dos fatos, o maior número de pessoas e instituições envolvidas em uma cobertura jornalística, principalmente aquelas que são objeto de acusações não suficientemente demonstradas ou verificadas.

Dispositivos como este têm justificado posições como a do professor Eugênio Bucci, expresso no artigo Profissões diferentes requerem códigos de ética diferentes, publicada no Observatório da Imprensa, em 5 de setembro de 2006, pouco antes do congresso extraordinário dos jornalistas de 2007, em Vitória, que revisou o Código de Ética da Profissão. Diz Bucci:

Jornalismo e assessoria de imprensa são duas profissões diferentes e não podem ser regidas por um mesmo Código de Ética. (...) Vejamos alguns pontos que ilustram muito bem o que é esse conflito de interesses a que me refiro. No artigo $10^{\circ}$, tanto na sua versão atual como na que se propõe para figurar no novo Código, lemos o seguinte:

'O jornalista não pode exercer cobertura jornalística pelo órgão em que trabalha, em instituições públicas e privadas, onde seja funcionário, assessor ou empregado'. 


\begin{abstract}
Aparentemente, o que está escrito ali é o que o jornalista não pode fazer. O que mais impressiona, porém, é o que esse artigo deixa subentendido como uma prática permitida ao jornalista: ele pode ser, ao mesmo tempo, repórter num jornal e assessor de imprensa num órgão de governo. Não há um veto para isso no Código de Ética. Quer dizer: o jornalista pode acumular as duas funções; só o que ele não pode é exercer cobertura jornalística, para o jornal em que trabalha, sobre a instituição em que também trabalha. Ocorre que a simples autorização tácita para esse acúmulo de atividades já é, em si mesmo, antiética. E o nosso Código não apenas o permite, ele consagra esse acúmulo de funções nitidamente conflitantes.
\end{abstract}

Conflito ululante. (Bucci, 2006)

A partir deste ponto, Bucci argumenta que há um conflito inevitável entre assessores e jornalistas de veículos, que a credibilidade de um profissional é questionável quando ele serve a dois senhores e que meramente estar em assessoria e em veículo é imoral em si mesmo. A conclusão, por óbvio, é de que são profissionais diferentes. Diz Bucci:

O assessor de imprensa, cuja atividade, eu repito, é digna, necessária, ética e legítima, tem como cliente não o cidadão, não o leitor, mas aquele que o emprega ou aquele que contrata os seus serviços. O que o assessor procura, com toda a legitimidade, é veicular a mensagem que interessa àquele que é o seu cliente, àquele que o contrata, e não há nada de errado com isso. É um ofício igualmente digno, mas não é jornalismo. A distinção entre os dois clientes estabelece uma distinção que corta de cima a baixo os dois fazeres.

Bucci mantém a posição pelos menos até 2010. No jornal O Estado de São Paulo, em 9 de setembro deste ano, publica artigo sobre o diploma de jornalista em que volta à carga na defesa de que assessor não é jornalista. Diz:

Ainda se acredita no Brasil que jornalistas e assessores de imprensa desempenham uma única profissão. Isso não faz sentido algum, nem aqui nem em nenhum outro lugar do mundo. (...) Ambas as atividades são essenciais e dignas, por certo, mas totalmente distintas uma da outra. No Brasil, no entanto, são vistas por muita gente como se fossem uma coisa só.

De forma menos categórica, Alberto Dines defende posição semelhante.

Hoje, você só pode ter um emprego na imprensa, mas há uma distorção que persiste no Brasil, que é a seguinte: o jornalista pode ser jornalista e, ao mesmo tempo, assessor de imprensa. Em Portugal, isso é inadmissível. Se o jornalista vai fazer um trabalho de assessoria, ele se licencia formalmente do sindicato, vai fazer o que tem que fazer e depois pode voltar. Pelo menos é uma forma de você dividir as duas atividades. Porque elas se parecem, mas são antípodas. Um assessor de imprensa é um jornalista, mas a serviço de uma matéria dirigida". (DE ABREU, 2003: 171) 
A restrição em Portugal está assentada no artigo $3^{\circ}$ do Estatuto do Jornalista Português, item 1.b, de 1999, que diz que a profissão de jornalista é incompatível com o desempenho de “funções remuneradas de marketing, relações públicas, assessoria de imprensa e consultoria em comunicação ou imagem, bem como de orientação e execução de estratégias comerciais". O Código Deontológico do jornalista português, de 1993, reforça esta posição, no item 10:

O jornalista deve recusar funções, tarefas e benefícios susceptíveis de comprometer o seu estatuto de independência e a sua integridade profissional. $\mathrm{O}$ jornalista não deve valer-se da sua condição profissional para noticiar assuntos em que tenha interesse"

(http://observatoriodaimprensa.com.br/feitos-

desfeitas/_ed823_no_brasil_e_em_portugal/

Na França, a visão é semelhante à de Portugal.

Na maior parte dos países, a prática de assessoria de imprensa está incluída na filosofia e no conjunto de técnicas de relações públicas. Pierre Fayard, da Université de Poitiers, França, explica que é inimaginável no modelo europeu um jornalista atuar como divulgador, porque a carta (similar a nosso registro profissional) é dada a pessoas vinculadas a órgãos de imprensa e, por isso, não podem atuar em atividades relacionadas às relações públicas. (DUARTE, 2001: 90)

Esta concepção, corrente, de que são profissões distintas está assentada em três erros fundamentais, pelo menos no Brasil: 1) que o dever do jornalismo com a sociedade deve ser provido pelo jornalista em si; 2) que assessores devem ser libertos de qualquer compromisso com a verdade e com o cidadão, já que estes não são os seus clientes; 3) que os veículos de comunicação vinculam-se ao interesse do cidadão e só a eles cabe o dever da verdade e do amplo contraditório.

Este artigo pretende demonstrar a falaciosidade destes princípios, sobretudo através da comparação de deontologias entre o direito e o jornalismo.

\section{IDEALIZAÇÃO POSITIVA DAS REDAÇÕES; IDEALIZAÇÃO NEGATIVA DAS ASSESSORIAS}

Os argumentos 2 e 3 têm pés de barro. Eles se erguem sobre a falácia de que jornalistas de redação são empregados por empresários da área de comunicação, com interesses normalmente profundamente contraditórios com o jornalismo, por razões econômicas ou políticas, mas têm como clientes o cidadão. Já assessores, empregados por empresários de diversas outras áreas, tem estas empresas como clientes, não o cidadão. 
Só uma razão estrutural justifica tal distinção: empresas de comunicação fazem comunicação; outras empresas têm a comunicação como uma das suas estratégias e obrigações. A sociedade, no entanto, caminhou para além disso. Jornais (públicos ou privados) e empresas (públicas ou privadas) devem estar submetidas ao dever de transparência com a sociedade. Leis democráticas no mundo se fiam neste princípio, pela aplicação da lógica pública a empresas privadas. Se fornecem serviços ao cidadão, devem ser transparentes com ele, independente da natureza jurídica, na qual, afinal de contas, jornais e outras empresas privadas são iguais na maioria dos casos.

Este valor nasce cedo, já na declaração de princípios de Ivy Lee, nos Estados Unidos, em 1906. Ao inaugurar a atividade de assessoria de imprensa, ele escreveu:

Este não é um serviço de imprensa secreto. Todo nosso trabalho é feito às claras. Nós pretendemos fazer a divulgação de notícias. Isto não é um agenciamento de anúncios. Se acharem que o nosso assunto ficaria melhor na seção comercial, não o usem. Nosso assunto é exato. Maiores detalhes sobre qualquer questão serão dados prontamente e qualquer diretor de jornal interessado será auxiliado, com o maior prazer, na verificação direta de qualquer declaração de fato. Em resumo, nosso plano é divulgar, prontamente, para o bem das empresas e das instituições públicas, com absoluta franqueza, à imprensa e ao público dos Estados Unidos, informações relativas a assuntos de valor e de interesse para o público. (CHAPARRO, 2011: 6)

É um conjunto de valores normativos que regulam a atividade em favor da transparência e do interesse público. Ferraretto e Ferraretto (2009) também separam claramente as funções de relações públicas, de publicidade e de assessoria de imprensa, concebendo cada uma delas com finalidades distintas. E também com valores morais diferentes.

É possível argumentar, em contrário, que o texto de Ivy Lee faz parte da sua estratégia para conseguir credibilidade perante os jornais. Da mesma forma, textos inaugurais sobre a imprensa informativa nos Estados Unidos, como os escritos por Joseph Pulitzer ${ }^{1}$, misturam estratégias de busca de credibilidade com a construção do norte utópico do jornalismo, do seu papel idealizado, que norteia sua história real. Portanto, uma certa falsidade dos textos não os anula.

Um exemplo de como a transparência é um valor em ascensão: a Anvisa, Agência Nacional de Vigilância Sanitária, deve fiscalizar se aquilo que as empresas de alimentos

1 Num dos seus textos mais famosos, Pulitzer escreve: "Nossa República e sua imprensa se elevarão ou cairão juntas. Uma imprensa capaz, desinteressada e de espírito público, com inteligência treinada para conhecer o direito e a coragem de fazê-lo, pode preservar essa virtude pública sem a qual o governo do povo é uma farsa e uma burla. Uma imprensa cínica, mercenária e demagógica produzirá no tempo um povo tão cínico quanto ela. O poder de moldar o futuro da República estará nas mãos dos jornalistas das gerações futuras. 
declaram, nos rótulos, conter nos seus produtos é verdade ou não e pode punir quem mente. No site da Agência, ela anuncia esta função, prevista em lei: "coordenar e executar o controle da qualidade de bens e de produtos relacionados no art. $4^{\circ}$ do Regulamento da Agência Nacional de Vigilância Sanitária" (http://www.anvisa.gov.br/institucional/anvisa/comp.htm, acessado em 16 de agosto de 2016). Faz isso em defesa do cidadão. Ou seja, a Anvisa impõe o dever de transparência e de verdade a empresas privadas.

Se as empresas que contratam os assessores devem, para bem da sociedade e da democracia, ser, cada vez mais, transparentes, porque então devemos admitir que os assessores de imprensa não devem estar submetidos ao mesmo dever de verdade dos jornalistas de redação? Porque devem estar submetidos aos desígnios ilegítimos dos seus empregadores, se eles eventualmente ocultam a verdade? Assessores devem ser julgados pelos mesmos princípios que impõem a verdade como dever dos outros jornalistas, aqueles que trabalham nas redações.

Esta visão, ideologizada, de que assessores agem em defesa dos interesses dos seus contratantes, mas jornalistas de redação agem a favor dos interesses do cidadão, mesmo contra os interesses dos seus contratantes, os empresários de comunicação, é falaciosa até a raiz. Pesquisa realizada recentemente pelo Departamento de Comunicação da Universidade Federal do Paraná, com jornalistas apenas do estado, aponta que os jornalistas veem nos donos dos jornais os principais atores interferentes por razões estranhas ao jornalismo, no conteúdo produzido por eles, com $46,6 \%$ das indicações. Os assessores ficam com os índices mais baixos, com $11,8 \%$.

Ou seja, é preciso lutar, com empresas da área de comunicação ou não, para que os jornalistas tenham, como cliente final, o cidadão, não seus empregadores diretos, mas há evidências que apontam que os maiores perigos, as maiores pressões, a maior restrição à liberdade jornalística está exatamente nas redações. Por isso, a concepção de Bucci, neste aspecto, é falsa e entrega as assessorias para os profissionais de marketing e assemelhados. Ela é teoricamente errada e politicamente desastrosa. É preciso conceber jornalistas em veículos e em assessorias como membros de uma mesma profissão, com funções distintas, resguardando tais distinções, mas vinculando ambos ao dever de busca da verdade e de amplo contraditório.

Aí adentramos no terreno em que Bucci tem razão: o amplo contraditório não deve valer para ambos, as regras deontológicas não devem ser homogêneas. Um jornalista que 
trabalha para um veículo de comunicação deve ouvir sempre todos os envolvidos numa cobertura, já que, em tese, ele não tem ou não deve ter lado. Argumenta Bucci:

Mas, aí vem a pergunta: isso vale para um assessor de imprensa? Será que um assessor de imprensa da Coca-Cola deve ouvir a Pepsi-Cola antes de divulgar um release? E um assessor da Igreja Universal do Reino de Deus, terá de ouvir sempre a Assembleia de Deus quando preparar notas sobre o fenômeno evangélico no Brasil? Se alguém aqui me disser que esse artigo vale para os que trabalham em redações, mas vale 'mais ou menos' para quem é assessor de imprensa, pois é isso o que se diz nos corredores, eu pergunto: como uma categoria pode pretender ter um código de ética cujos artigos valem para alguns de seus integrantes e não valem para outros? (2006)

Este argumento fundamenta a exclusão dos assessores de imprensa da obrigação de ouvir "o maior número de pessoas e instituições envolvidas em uma cobertura jornalística", textual no Código de Ética. É usado por Bucci, porém, como mais um motivo para considerar jornalistas em assessoria e em veículos como membros de profissões distintas. Com base no mesmo fundamento, de que tal distinção acaba por materializar duas profissões, há jornalistas que defendem o fim desta ressalva no código. Se o jornalismo se baseia na obrigação de publicar informações verídicas e checadas e no amplo contraditório, excluir uma das obrigações para assessores os tornaria profissionais pela metade. Seria, assim, um contrassenso. A ética jornalística deveria se aplicar a todos.

Os dois princípios (dever de verdade e amplo contraditório) se expressam firmemente no Código de Ética. Diz o artigo $4^{\mathrm{o}}$ : "O compromisso fundamental do jornalista é com a verdade no relato dos fatos, razão pela qual ele deve pautar seu trabalho pela precisa apuração e pela sua correta divulgação." O $7^{0}$ detalha o dever da apuração: "O jornalista não pode: (...) II - submeter-se a diretrizes contrárias à precisa apuração dos acontecimentos e à correta divulgação da informação.” O 12 faz o mesmo, em outros aspectos:

O jornalista deve: (...) II - buscar provas que fundamentem as informações de interesse público; (...) V - rejeitar alterações nas imagens captadas que deturpem a realidade, sempre informando ao público o eventual uso de recursos de fotomontagem, edição de imagem, reconstituição de áudio ou quaisquer outras manipulações.

No mesmo artigo, esta obrigação se desdobra no dever de retificação e na luta pelo direito de resposta, posterior à publicação das notícias: “O jornalista deve: (...) VI - promover a retificação das informações que se revelem falsas ou inexatas e defender o direito de resposta às pessoas ou organizações envolvidas ou mencionadas em matérias de sua autoria ou por cuja publicação foi o responsável.” A relação com o interesse público e o amplo 
contraditório também se desdobram no Código. O artigo 6º diz: “É dever do jornalista: (...) II - divulgar os fatos e as informações de interesse público; III - lutar pela liberdade de pensamento e de expressão; IV - defender o livre exercício da profissão." O $7^{\circ}$ também proíbe qualquer ação contrária à liberdade de expressão. Diz: “O jornalista não pode: (...) III impedir a manifestação de opiniões divergentes ou o livre debate de ideias."

A introdução da palavra "verdade" no código dividiu opiniões no Congresso Extraordinário de Vitória, em 2007. Quimérica, inacessível, fraudulenta, tal obrigação imporia ao jornalismo algo que ele não poderia fazer e serviria apenas como discurso legitimador de uma narrativa ideológica. Mesmo sob críticas, a palavra ficou, como em um grande número de códigos deontológicos do jornalismo no mundo.

E deve mesmo ficar. A verdade é quimérica e inacessível, o jornalismo com sua pressa e seus métodos simples, muito menos confiáveis que os métodos científicos, não poderia atingir verdade alguma. A ciência, com muito maior rigor metodológico, não postula verdade no que faz. Tampouco, porém, postula que qualquer teoria tenha tanta validade quanto outra apenas pelo fato de ter sido formulada. Por isso, a ciência rejeita o desenho inteligente como explicação equivalente, por ser tão boa hipótese quanto, à seleção natural. A ciência tem formas de validar o conhecimento que produz, em cada um dos seus campos, de forma autônoma. Isso se chama princípio da autolegitimação dos campos científicos.

Se a ciência não advoga que o que faz é verdade, por que então o jornalismo precisaria disso? Ao longo do tempo de consolidação do jornalismo como nós o conhecemos, desde a segunda metade do século XIX e ao longo de praticamente todo o XX, a perseguição da quimérica verdade, da quimérica objetividade (SMITH, 1978), do retrato fiel da realidade fez o jornalismo assumir compromissos para chegar a isso e desenvolver seus próprios métodos para construir um conhecimento específico (MEDITSCH, 2005). A verdade no jornalismo tem a função das utopias: falsas, inalcançáveis, mas imprescindíveis, elas fazem a sociedade caminhar, projetam o futuro, criam coisas apenas por apontar o caminho, por estimular o caminhar. O jornalismo poderá abrir mão da perseguição da verdade no dia que tiver clareza da importância dos métodos jornalísticos para a garantia da qualidade da informação que fornecemos à sociedade e o desapego da verdade não seja justificativa para que qualquer narrativa de um acontecimento seja tão boa quanto qualquer outra, já que não há verdade. A relativização das narrativas aponta para a extinção do jornalismo em si mesmo. Se ele não tem maior capacidade de narrar o mundo de forma mais próxima da verdade, então o jornalismo não é necessário para a sociedade. Por isso, precisamos da utopia da verdade, que norteia 
nosso código. E com base nela construímos procedimentos que definem o jornalismo, sem os quais um texto não pode ser considerado jornalístico, independente do conteúdo.

Perseguindo sonhos, por vezes os afirmando como possíveis, talvez até no limite da fraude, o jornalismo foi construindo procedimentos voltados para a garantia de qualidade de informação fornecida à sociedade (SMITH, 1978). Por outro lado, assumindo o papel de defensores do direito de expressão da sociedade, como direito fundamental do cidadão, os jornalistas foram construindo uma outra forma de verdade: aquela que emerge da diversidade, dos diversos olhares. São verdades contraditórias que, às vezes, se opõem. Em algumas situações, a verdade contraditória parece desobrigar o jornalista da verdade factual. Na falta de uma informação checada, jornalistas publicam duas versões e tudo bem. Esta é uma leitura torta dos nossos princípios. Estamos obrigados à verdade factual onde ela é possível, não podendo substituir o trabalho de checagem de informação pela diversidade das versões. Tampouco em questões controversas podemos reduzir tudo a uma verdade absoluta. Se trocamos a checagem de uma denúncia pelo bate-boca entre as fontes, erramos moralmente. Se trocamos o debate sobre o futuro da sociedade por alguma perspectiva totalizante, erramos igualmente.

O jornalismo está obrigado às duas verdades: a factual e a contraditória. E deve lidar com os conflitos entre elas, com correção ética, sem usar uma para perdoar a falta da outra. Por que então pode o assessor de imprensa estar excluído da segunda verdade, da contradição? As posições que advogam que esta ressalva torna os assessores outra profissão, seja para criticar a ressalva ou para separar os assessores dos jornalistas, impõem ao indivíduo jornalista as obrigações do sistema jornalístico. Eis a falácia número 1 que devo negar: as obrigações do jornalismo cabem ao sistema jornalístico, em primeiro lugar, e aos jornalistas, dentro deste sistema, mas não a cada jornalista individualmente de forma igual.

\subsection{O sistema jurídico}

Bucci usa o campo jurídico a favor da sua tese de que assessores não são jornalistas. Vamos ao texto:

Juízes, advogados e promotores públicos são todos operadores do Direito, egressos das faculdades de Direto. Todos lidam com as leis, com a Justiça, fazem funcionar o sistema jurídico. Não obstante, sabem que exercem funções distintas e, por isso, pertencem a ordens profissionais distintas, filiam-se a códigos de ética específicos. Não porque advogados pretendam promover a injustiça em oposição a juízes que pretendem fazer valer a lei, 
mas porque seus ofícios concentram particularidades que são inconciliáveis e, sem demérito para promotores, advogados e juízes, essas três categorias são categorias diferentes. É assim que, ao se tornar juiz de direito, um advogado deve se desfiliar da Ordem dos Advogados do Brasil, devolvendo sua carteira à entidade. (2006)

A comparação é útil, mas é preciso minimizar exageros (não existem várias deontologias no campo jurídico) e recolocá-la de forma mais precisa. A arquitetura deontológica dos advogados faz exatamente o contrário do que diz Bucci: ela especifica funções, algumas incompatíveis, outras nem tanto, explicita contradições de interesses e subordina todos os agentes do campo jurídico a um mesmo norte moral: a promoção da justiça e o funcionamento do Estado de Direito.

Juízes não podem advogar não por imposição da OAB, mas da Constituição Federal, que diz no seu artigo 95, parágrafo único: “Aos juízes é vedado: I - exercer, ainda que em disponibilidade, outro cargo ou função, salvo uma de magistério". E note-se que tudo está vedado, exceto o magistério, não apenas a advocacia. O artigo 93 da Constituição, no entanto, defende que a advocacia é requisito para ser juiz, e diz no seu inciso I:

ingresso na carreira, cujo cargo inicial será o de juiz substituto, mediante concurso público de provas e títulos, com a participação da Ordem dos Advogados do Brasil em todas as fases, exigindo-se do bacharel em direito, no mínimo, três anos de atividade jurídica e obedecendo-se, nas nomeações, à ordem de classificação. (1994)

$\mathrm{A} \mathrm{OAB}$, ao contrário de se afastar da magistratura, a acompanha. O mesmo princípio se expressa na obrigação constitucional da Ordem de compor listas tríplices para tribunais superiores, regrada no artigo 51 da entidade: “A elaboração das listas constitucionalmente previstas, para preenchimento dos cargos nos tribunais judiciários, é disciplinada em Provimento do Conselho Federal".

Parece evidente que as leis que regulam o campo do direito e mesmo os princípios deontológicos do campo concebem advogados, juízes, defensores públicos e promotores como funções de um mesmo sistema, operando para um mesmo fim. Diz o artigo $9^{\circ}$, do regulamento da Ordem:

Exercem a advocacia pública os integrantes da Advocacia-Geral da União, da Defensoria Pública e das Procuradorias e Consultorias Jurídicas dos Estados, do Distrito Federal, dos Municípios, das autarquias e das fundações públicas, estando obrigados à inscrição na $\mathrm{OAB}$, para o exercício de suas atividades. Parágrafo único. Os integrantes da advocacia pública são elegíveis e podem integrar qualquer órgão da $\mathrm{OAB}$. 
Note-se o parágrafo: advogados de qualquer poder público devem integrar a ordem. Juízes não, é claro, porque não são advogados. O artigo 10 do mesmo regulamento explicita a homogeneidade deontológica:

Os integrantes da advocacia pública, no exercício de atividade privativa prevista no Art. $1^{\circ}$ do Estatuto, sujeitam-se ao regime do Estatuto, deste Regulamento Geral e do Código de Ética e Disciplina, inclusive quanto às infrações e sanções disciplinares.

\subsection{Conflitos de interesses}

O que a deontologia dos advogados interdita, de fato, é a defesa de interesses contraditórios. O artigo 17 do Regulamento da OAB, por exemplo, diz: "Os advogados integrantes da mesma sociedade profissional, ou reunidos em caráter permanente para cooperação recíproca, não podem representar em juízo clientes com interesses opostos”. Este princípio se manifesta em outros artigos e transcende o próprio regulamento da Ordem. No regimento da Comissão de Ética da Advocacia Geral da União, está expresso o mesmo princípio, no artigo 39, sobre conflito de interesse:

incumbe à CEAGU (Comissão de ética da AGU): I - efetuar a análise preliminar sobre a existência ou não de potencial conflito de interesses nas consultas que lhes forem encaminhadas; II- autorizar o agente público da AGU e seus órgãos vinculados a exercer atividade privada, quando verificada a inexistência de potencial conflito de interesses ou a sua irrelevância. (2014)

Num mundo ideal, no campo jurídico e no jornalístico, o objetivo deveria ser a completa separação das funções, mas se o direito, campo com muito mais condições materiais e com debate ético muito mais denso, não chegou a isso ainda, impor esta rigidez ao jornalismo é exagero e, sem condições institucionais adequadas, contribui para o mal que critica, lança a área de assessoria de imprensa para toda sorte de profissionais com visão meramente instrumental da comunicação. Daí porque tal posição, defensável em tese, é politicamente desastrosa, tanto para os compromissos inegáveis da assessoria de imprensa com a verdade factual, quanto para seus compromissos, parciais, com o amplo contraditório.

Mas sigamos na comparação. Direito, medicina e jornalismo são as três profissões canônicas, aquelas que, com distinções, tem mais atributos das profissões elencados por Greenwood (TRAQUINA, 2005). Cada uma destas profissionais defende um bem fundamental para a sociedade. O direito é responsável pela justiça, que deve ser igual para todo e qualquer cidadão; a medicina é responsável pela preservação da vida, direito de todo 
ser humano; o jornalismo, pelo direito do cidadão à informação fundamental para o funcionamento da democracia. Estes são os grandes nortes utópicos destas profissões, o motivo porque a sociedade concede a elas alguns privilégios. Estas três profissões são exploradas economicamente e muitas vezes o caráter mercantil se opõe ao dever moral, à missão maior focada nos interesses da sociedade. Um médico, diante de um ser humano, qualquer ser humano, que tenha sofrido um acidente, por exemplo, tem obrigação moral de atender e tentar salvar aquela vida, independente do plano de saúde ou de qualquer pagamento. No direito, as coisas são menos urgentes, mas o princípio se materializa na militância, por exemplo, da Ordem dos Advogados do Brasil pela criação das defensorias públicas. Todo cidadão tem direito à defesa; a OAB luta por isso. A sociedade não entende, muitas vezes, advogados que defendem assassinos e estupradores, mas eles devem fazê-lo, por imposição ética. Diz o artigo 21 do regulamento da Ordem: "É direito e dever do advogado assumir a defesa criminal, sem considerar sua própria opinião sobre a culpa do acusado".

Todo cidadão tem direito à defesa, é um princípio moral do direito. $\mathrm{O}$ mesmo norte guia (ou deveria guiar) defensoria, promotoria, advogados e juízes. Na comunicação, a defesa dos direitos do cidadão se materializa, por exemplo, no debate sobre o Plano Nacional de Banda Larga. Acessar informação e se manifestar numa democracia digital é direito de qualquer pessoa.

A questão da assessoria ser ou não atividade jornalística emerge quando o dever do amplo contraditório, que guia as ações individuais dos profissionais do campo, é absolutizada como dever exclusivamente individual. O direito sabe bem que a justiça, que guia advogados, juízes, promotores e defensores, não cabe a nenhum deles especificamente e cabe a todos também. Apenas a relação entre eles, cada um com seu papel, mas todos movidos pelo mesmo princípio é que permitirá a promoção da justiça. Ela não poderá existir sem acusação, defesa e juiz.

Os papéis distintos no direito permitem até mesmo que um advogado minta em juízo, para não produzir provas contra seu cliente, com base no princípio de que ninguém é obrigado a produzir prova contra si mesmo, o que abrange as partes e os advogados.

O direito ao silêncio é apenas a manifestação da garantia muito maior, que é a do direito da não auto-acusação sem prejuízos jurídicos, ou seja, ninguém que se recusar a produzir prova contra si pode ser prejudicado juridicamente. (Santos, 2009). 
Testemunhas podem ser presas por perjúrio se mentirem perante um juiz; o réu e seu advogado não. Isso não significa que assessores possam mentir como parte do seu papel. Não temos que copiar a deontologia jurídica do Brasil. Assessores não podem ocultar informação factual e devem poder ser representados nas comissões de ética da categoria se o fizerem, mas também não devem ser obrigados ao amplo contraditório como é o caso dos jornalistas de veículos. E não há problema nisso. $\mathrm{O}$ assessor tem o compromisso com a ampla contradição na parte que lhe diz respeito. Não pode, por isso, criar obstáculo no acesso às fontes da sua organização, nem tampouco pode interditar o acesso às fontes de posição contrária à sua. Este é o seu papel na ampla contradição, sem chegar a ter que entrevistar a Pepsi, trabalhando na Coca. A Pepsi é que deve promover isso, como cada advogado defende seu lado. E assim funciona o sistema.

Similar à luta pela criação das defensorias, as organizações da categoria dos jornalistas, como a Fenaj - Federação Nacional dos Jornalistas, Sindicatos de Jornalistas, Associação Brasileira de Imprensa, Arfoc - Associação dos Repórteres Fotográficos e Cinematográficos, devem lutar pela criação de mecanismos que permitam que os segmentos da sociedade que não têm organização ou poder para criar suas assessorias tenham algum serviço desta natureza. Isso tem acontecido, parcamente, mas tem. A Andi - Agência Nacional de Direitos da Infância - promove pautas deste segmento difuso, que jamais poderia criar sua própria assessoria, como pode a Pepsi e a Coca-Cola. Os assessores fazem parte do sistema jornalístico. Tem que ser concebidos assim, senão deixam de ser um direito da sociedade e passam a ser um instrumento de quem tem poder econômico para tanto. Devemos mirar ainda nas utopias. Por isso, separar jornalistas de assessoria dos jornalistas de veículos é um erro político e moral, contrário aos princípios do jornalismo. Assessoria não pode ser atividade meramente estratégica e instrumental. É jornalismo, faz parte do sistema jornalístico, não tem as mesmas obrigações estritas, mas se orienta pelos mesmos princípios que guiam ou deveriam guiar os jornalistas de veículos. Assim como advogados e juízes compartilham os mesmos princípios morais, mas não as mesmas regras.

\subsection{Liberdade profissional}

Espera-se, é verdade, que jornalistas em veículos tenham mais liberdade jornalística e maior compromisso com a verdade factual e com a verdade contraditória, assim como se espera que um juiz seja mais equilibrado que defesa e acusação. A categoria deve lutar por esta liberdade, por condições mais claras de manutenção dos compromissos morais do 
jornalismo. Esta condição é também um norte utópico, um lugar para onde devemos caminhar. Tomar o ponto de chegada como condição realizada é equívoco teórico.

O jornalismo brasileiro, como de boa parte da América Latina, se desenvolveu como atividade privada com fortes relações com o Estado, muitas vezes relações promíscuas, chegando à corrupção (BARBOSA, 2007). Donos de veículos de comunicação brasileiros são, via de regra, patrimonialistas e enxergam suas empresas duplamente: como negócio e como instrumentos políticos.

Além desta condição política, o jornalismo também é pressionado pela sua função comercial, pela busca de audiência, de tiragens, pela concorrência pelo furo (ARBEX Jr, 2002). Como funciona no direito, onde um lado deve fiscalizar o outro, assessorias e veículos devem manter relações que são complementares, mas também de vigilância, ambos operando pela correção da informação jornalística e pela ampla contradição. Assessores devem proteger seus assessorados quando não ouvidos, devem facilitar o trabalho dos veículos, mas também fiscalizar a divulgação correta de informações. Um exemplo talvez funcione melhor.

\subsection{Vazamento de césio na UFPR}

Em 2009, quando eu exercia o cargo de chefe da Assessoria de Comunicação Social da Universidade Federal Paraná enfrentei uma pequena crise de mídia. Num procedimento de rotina, funcionários retiravam um equipamento chamado cintilizador de um depósito para levar para outro. Este equipamento utiliza cápsulas de césio. Ao verem o sinal de radioatividade em uma peça, os funcionários se assustaram e isolaram a área, achando que poderia se tratar de um vazamento de material radioativo. História fantástica, ainda mais que rememorava um episódio famoso de vazamento de césio, em Goiânia, em 1987.

Manchete no G1, em 5 de setembro de 2009, dizia: "Vazamento de césio 137 isola universidade no Paraná" ${ }^{2}$. Isto aconteceu de manhã. Na hora do almoço, a Globo de Curitiba estava com uma equipe com link ao vivo transmitindo direto do local. Os demais veículos todos queriam informações, queiram dar a manchete, fantástica: "Vazamento de césio na UFPR". Uma fonte imprevidente ligada à Anvisa - Agência Nacional de Vigilância Sanitária - disse que, em tese, se havia a marcação de césio tinha césio. Pronto: suspeita confirmada por uma fonte legitimada. Nenhum veículo apurou adequadamente, sequer desconfiou da história. 
Quem tinha o maior interesse em informações precisas era a UFPR e a sua assessoria. Durante a tarde, conseguimos informação com os pesquisadores da área, descobrimos que a cápsula de césio tinha sido retirada, estava num compartimento de chumbo, guardada adequadamente, esperando ser recolhida pelo poder público competente. Além disso, já estava totalmente enfraquecida. A UFPR mediu a radiação com um contador geiger, visitamos o local onde a cápsula estava guardada, falamos com o funcionário da empresa que vendeu o equipamento e que foi responsável pela retirada do material, apuramos tudo. Apuramos o que aconteceu e o que não aconteceu. Descobrimos todos os detalhes. No dia seguinte, o R7 publicava a seguinte manchete: "Peça que provocou isolamento da UFPR não contém Césio-137”3.

Se fosse mesmo um vazamento, não poderíamos esconder, mas teríamos as informações para tomar medidas que minimizassem os danos à imagem da universidade, o que era meu dever profissional, legitimado pelo código de ética dos jornalistas que defende o direito a honra e à preservação da imagem dos cidadãos. Agir também é comunicação. Nunca cogitamos esconder informações se fossem ruins.

Neste episódio, quem queria fazer jornalismo era a assessoria e não os veículos. Eles queriam a história e a manchete, espalhando pânico e desinformando. Jornalismo era nossa salvação. Ou seja, os papéis são complementares. A UFPR não divulgaria, com estardalhaço, uma suspeita de vazamento de césio, nem os veículos se dedicariam aos detalhes da história. Cada um cumprindo seu papel, acabamos ao fim com a informação correta e com uma nova entrevista com a fonte imprevidente da Anvisa reconhecendo que não havia césio.

Podem argumentar, no sentido contrário, que estes episódios são minoritários ou que os veículos cometem deslizes, apenas isso. Mesmo que fosse, acontece regularmente, porque a busca da manchete, pelo caráter mercantil da imprensa brasileira, é constitutiva das práticas cotidianas do jornalismo comercial, não incidental. Por outro lado, gestão de crise de imagem tem materializado uma área de estudos e de atuação profissional cada vez mais prolífica. E moralmente legítima, necessária, pela preservação da imagem dos assessorados e pela correção das informações.

Além disso, nas relações cotidianas das assessorias com redações, jornalistas esperam que assessores facilitem o acesso às fontes (e não esperam que indiquem as fontes do outro lado. Isso cabe a outro assessor, como cabe também ao editor parte da responsabilidade pela qualidade da informação publicada. Jornalismo é um sistema, não produto de um

3 https://noticias.r7.com/cidades/noticias/peca-que-provocou-isolamento-da-ufpr-nao-contem-cesio-137-20091106.html, acessado em 16 agosto de 2016. 
indivíduo). Jornalistas esperam que assessores consigam boas informações, completas, precisas. Jornalistas esperam, enfim, que assessores sejam e ajam como jornalistas.

\section{CONSIDERAÇÕES FINAIS}

A alegação de que a ressalva quanto ao amplo contraditório no código de ética e a relativa flexibilidade com o duplo emprego justificam a separação do jornalismo em dois (mídia e fora da mídia, cada um hoje com cerca de 50\% da categoria) (LIMA, 2012) joga fora o bebê com a água da bacia. Na questão da exclusividade, temos que lutar por melhores condições institucionais e materiais para o exercício da profissão, apontando para o fim do duplo emprego, na maioria das situações.

É defensável e acontece, de forma mais tímida no nosso campo, a discussão do conflito de interesses. Algumas empresas, como a Folha de São Paulo e a Gazeta do Povo, já exigem exclusividade dos seus profissionais. Nosso código de ética toca no assunto, de forma tímida, provavelmente porque não há condições materiais para uma separação estrita. Jornalistas ganham mal e se sujeitam a duplas jornadas não por serem desonestos, mas porque precisam. Mas devemos estender o debate do conflito de interesses não apenas para a acumulação de funções de assessoria e redação, mas também para o exercício de dois empregos em redações de veículos diferentes. Jornais devem concorrer entre si e não colaborar. Eis outro bom debate.

De qualquer forma, o aprimoramento das regras morais da profissão deve vir acompanhado da criação das condições materiais para tanto. Isso não é um problema no campo jurídico, onde os salários no poder público estão entre os melhores da República.

Quanto ao amplo contraditório, temos que especificar melhor as regras no código de ética, mantendo os princípios da verdade factual e da verdade contraditória, tanto para jornalistas assessores quanto para jornalistas de redação, deixando mais claros os papéis de cada um no sistema jornalístico.

Se as assessorias no resto do mundo têm papel instrumental, ligado ao marketing, o Brasil tem uma especificidade na forma como desenvolveu a área. Isso coloca o país na vanguarda e vincula a assessoria de imprensa aos direitos do cidadão, sobretudo, e à democracia, não apenas ao funcionamento do sistema econômico. Abrir mão disso, voluntariamente, dando um passo atrás ou copiando modelos piores sob qualquer alegação é 
um desserviço para a sociedade, piorando a qualidade de informação que o sistema oferece aos cidadãos. Jornalistas não têm direito de defender tal posição.

\section{REFERÊNCIAS}

ARBEX JR, José. Showrnalismo: a notícia como espetáculo. Casa Amarela, 2002.

BUCCI, Eugênio. Assessor de imprensa é jornalista. O Estado de São Paulo, 2010.

Disponível em http://opiniao.estadao.com.br/noticias/geral,assessor-de-imprensa-e-jornalistaimp-,607224. Acessado em 12 de Agosto de 2016.

BARBOSA, Marialva. História cultural da imprensa Brasil-1900-2000. Mauad Editora Ltda, 2007.

BUCCI, Eugênio. Jornalistas \& assessores de imprensa, profissões diferentes requerem códigos de ética diferentes. Observatório da imprensa, 2006. Disponível em http://observatoriodaimprensa.com.br/jornal-de-debates/profissoes-diferentes-requeremcodigos-de-etica-diferentes/. Acessado em 12 de agosto de 2016.

CHAPARRO, Manuel Carlos. Cem Anos de Assessoria de Imprensa. In: Duarte, Jorge. Assessoria de Imprensa e relacionamento com a mídia: teoria e técnica. $4^{a}$ edição. São Paulo: Atlas, 2011.

CÓDIGO de Ética dos Jornalistas Brasileiros. Federação Nacional dos Jornalistas. Vitória (ES), 2007.

CÓDIGO deontológico do jornalista português. Lisboa, 1993.

DE ABREU, Alzira Alves; LATTMAN-WELTMAN, Fernando; ROCHA, Dora. Eles mudaram a imprensa: depoimentos ao CPDOC. FGV Editora, 2003.

DUARTE, Jorge Antonio Menna. Assessoria de imprensa: o caso brasileiro. IntercomRevista Brasileira de Ciências da Comunicação, 2001, 24.1.

ESTATUTO DO JORNALISTA PORTUGUÊS. Lisboa, 1999.

(http://www.jornalistas.eu/?n=26, accessado em 16 de agosto de 2016)

FEDERAÇÃO NACIONAL DOS JORNALISTAS PROFISSIONAIS (FENAI). Manual de Assessoria de Imprensa. São Paulo: Comis- são Permanente e Aberta dos Jornalistas de Assessoria de Imprensa do Sindicato dos Jornalistas Profissionais no Estado de São Paulo, 1986.

FERRARETTO, Elisa Kopplin; FERRARETTO, Luiz Artur. Assessoria de imprensa: teoria e prática. Summus Editorial, 2009.

LIMA, Samuel Pantoja. Perfil do jornalista brasileiro: características demográficas, políticas e do trabalho jornalístico em 2012. Florianópolis: Insular, 2013.

MEDITSCH, Eduardo. O jornalismo é uma forma de conhecimento?. Media \& Jornalismo, v. 1, n. 1, 2005. 
REGIMENTO Interno da Comissão de Ética da Advocacia-Geral da União, portaria 222, de 3 de julho de 2014. Disponível em file:///C:/Users/Mario/Documents/portaria_n_222_-_0307.pdf. Acessado em 14 de agosto de 2016.

REGULAMENTO geral do Estatuto da Advocacia e da OAB. Brasília, 1994. Santos, Luciano Aragão. O direito de não produzir prova contra si mesmo: "Nemo tenetur se detegere". Disponível em http://www.direitonet.com.br/artigos/exibir/5283/Odireito-de-nao-produzir-prova-contra-si-mesmo-Nemo-tenetur-se-detegere. Acessado em 16 de agosto de 2016.

SMITH, Anthony. The long road to objetivity and back again: the kinds of truth we get in journalism in Newspaper history: from the seventeenth century to the present day. Ed. by G Boyle; J. Curran \& P. Wingate. London: Canstable, 1978.

TRAQUINA, Nelson. Teorias do Jornalismo: a tribo jornalística-uma comunidade interpretativa transnacional. Florianópolis: Insular, v. 2, 2005.

TRAQUINA, Nelson. Teorias do Jornalismo: a tribo jornalística-uma comunidade interpretativa transnacional. Florianópolis: Insular, v. 1, 2005.

Vazamento de césio 137 isola universidade no Paraná.

(http://g1.globo.com/Noticias/Brasil/0,„MUL1368254-5598,00-

VAZAMENTO+DE+CESIO+ISOLA+UNIVERSIDADE+NO+PARANA.html, acessado em 16 de agosto de 2016)

Original recebido em: 19 de agosto de 201

Aceito para publicação em: 21 de outubro de 2017

Mário Messagi Jr

Mário Messagi Júnior é professor de Comunicação da UFPR. Jornalista, é mestre em Letras/Linguística pela UFPR e doutor em Ciência da Comunicação pela Unisinos.

Esta obra está licenciada sob uma Licença Creative Commons. 